\title{
ANTENATAL MANAGEMENT INFORMATION SYSTEM (CASE STUDY: CHINA- UGANDA FRIENDSHIP HOSPITAL, NAGURU)
}

\section{Edison Kagona and Timothy Isaiah}

\author{
Department of Computer Science \& Information Technology, International University of \\ East Africa, P.O.Box 35502 Kampala
}

Cite this article:

Edison K., Timothy I. (2022), Antenatal Management Information System (Case Study: China-Uganda Friendship Hospital, Naguru). British Journal of Computer, Networking and Information Technology 5(1), 11-42. DOI: 10.52589/BJCNIT_FVEUH8T C.

\section{Manuscript History}

Received: 13 Nov 2021

Accepted: 1 Dec 2021

Published: 14 Feb 2022

Copyright $(\odot) 2022$ The Author(s). This is an Open Access article distributed under the terms of Creative Commons AttributionNonCommercial-NoDerivatives 4.0 International (CC BY-NC-ND 4.0 ), which permits anyone to share, use, reproduce and redistribute in any medium, provided the original author and source are credited.
ABSTRACT: To eradicate fetal deaths and stillbirths, the World Health Organization (WHO) set up antenatal care guidelines to help expectant mothers through this period. In Uganda today, it is estimated that at least $90 \%$ of the expectant mothers receive antenatal care, and with such a large number of people receiving this service, data is collected manually with pen, which makes it a long process and cumbersome to search specific records during emergencies and analysis of data for proper decision making. Therefore, there is a need for an antenatal management information system. The software is sectioned into registration, triage and consultation. The records officer handles registration of patients, patient visits, viewing and printing patient statistics. The senior clinical officer handles triaging the patient and capturing their vitals, viewing and printing patient statistics. The head midwife handles the monthly progress examination, and views and prints patient statistics. All these processes happen in real time. This system is designed to overcome the problems identified in the current antenatal management information system. The interfaces for the new system were implemented using JSP, Bootstrap and Javascript. PostgreSQL was also used for implementing the system database while Spring was used to create interactivity with the database. After the implementation, the new system was then tested and validated. When developing the system, the focus was on making the whole process of information management in the antenatal department faster, more convenient and efficient.

KEYWORDS: Antenatal Care, Antenatal Management, Information System, Uganda 


\section{INTRODUCTION}

To eradicate preventable maternal deaths and to reduce the Maternal Mortality Rate (MMR), world leaders agreed at the Millennium Summit in September 2000 to improve the lives of the world's poor people through the acceptance of the World Health Organization's (WHO) Fifth Millennium Development Goal (Alkema, 2016). By 2000, WHO estimated lifetime risk of maternal deaths of 1 in 16 in Sub-Saharan Africa while it was 1 in 2800 in developed countries. This huge deviation in the rate of maternal deaths is due to the differences in access and use of maternal health care services (Mpembeni, 2007).

WHO defines antenatal care (ANC) as the care provided by skilled health care professionals to pregnant women and adolescent girls to ensure the best health conditions for both mother and baby during pregnancy (Organization, 2016). ANC as the essential entry point to maternal health care services is equipped to impart preventive service, diagnose and treat complications during pregnancy, and provide proper information to promote the use of skilled attendance at birth (Conrad, 2012). Research has shown that the coverage of ANC services in Uganda is generally high, with more than $90 \%$ of all women making at least one visit (UNICEF \& United Nations Children's Fund, 2008; Conrad, 2012). With all these high coverage rates, ANC ought to be of undoubtedly high quality to serve as an effective entry point to all other maternal care services (Conrad, 2012).

In Uganda today, ANC is provided and records taken by hand pen, archived in books, and antenatal cards as suited to the particular facility providing the service. With numbers skyrocketing as high as $90 \%$ of the women making at least one visit (UNICEF \& United Nations Children's Fund, 2008; Conrad, 2012), this method of capturing and storing data becomes very cumbersome given the difficulties the country faces such as shortage of health workers (Ministry of Health, 2015) and concerns around long waiting times, unofficial fees in public facilities, and poor attitude among health workers (Jitta J, 2008; Conrad, 2012) that in turn water down the quality of service provided.

The proposed AMIS seeks to provide better service delivery tailored for the Ugandan Health Sector but also resolve the weaknesses conveyed by the reviewed systems by auto-generating client reports through integrated information processing and storage, increased data security using role-based and rule-based access rights. The system being web-based solves the problem of compatibility there for AMIS; this would be the ideal solution to information management in the antenatal department and also key in informative decision making by the respective bodies in charge.

\section{METHODOLOGY}

The study employed a qualitative methodology of research in which the opinions of senior nursing officers, midwives, interns, and records officers were sought and then contextualized according to their understanding. The case study was China-Uganda Friendship Hospital, Naguru. The information which was conformed to other public hospitals countrywide and gave the basis for the design of the system. 


\section{System Study Tools and Techniques}

Under the system study, more data on the Antenatal Management Information System was collected, and interviews were carried out using questionnaires, and observations to understand the existing system.

\section{Interviews}

Structured and unstructured interviews were used as techniques to acquire information on the current system. Unstructured interviews were used to establish rapport and comfort with the participant in several rounds, and it was used when interviewing random people. Structured interviews were used when interviewing specific individuals in offices since the technique adheres to the use of a guiding protocol to target a specific phenomenon or experience.

For the structured interviews, we prepared a form that served as a questionnaire made of both close-ended and open-ended questions to acquire needed information from the different staff that include records officer, interns, senior clinical officer and head midwife who actively participate in the system flow.

\section{Observation}

As part of the study, observation was employed to engage the research team in the workflow to understand the client-flow from the time of arrival until the discharge.

\section{System Analysis}

After a successful data collection, it is important to carefully analyze the data to accurately extract the desired information. The desired information includes functional requirements, non-functional requirements, and feasibility analysis. Several tools can be applied to analyze the data acquired; however, SPSS was chosen as a tool to be used for the data analysis of the quantitative data gathered. SPSS is a software package used for interactive or batched statistical analysis.

The fact-finding methods used in this research comprises both quantitative methods and qualitative methods. A questionnaire survey is a quantitative method of data collection whereas an interview is a qualitative data collection method. Observation can be carried out in both quantitative and qualitative context but in this research, the quantitative context was used. Statistical analysis was applied to the quantitative data collected. Qualitative data can be analyzed in five ways: content analysis, narrative analysis, discourse analysis, framework analysis, and grounded theory. However, discourse analysis was used because the data was collected from an interview and discourse analysis is used for analyzing data from natural talking and written text.

\section{System Design}

The system was designed following Object-Oriented Analysis and Design (OOAD) which employed tools such as Data Flow Diagrams (DFD), Entity Relation Diagrams (ERD), and Activity Diagrams, etc.

Data Flow Diagrams exhibit the graphical representation of point-to-point flow of data through the proposed system. On the other hand, Entity Relation Diagrams exhibit the role- 
based functionalities of the system, who and how the different actors interact with the system at an encapsulated level.

\section{System Implementation}

The system was developed using spring - a Java framework - to handle the backend; the programming language of choice is Java because of its sophisticated security, JavaScript/jQuery, HTML, Bootstrap for the frontend because of their wide base of support features for web development. The IDE is NetBeans. The DBMS is PostgreSQL running over Apache Tomcat Server. The system is based on the MVC architecture.

\section{a. Spring}

Spring is a framework designed to simplify Java development. It is a lightweight container which promotes Plain Old Java Object based development, loose coupling through dependency injection and coding to interfaces. It uses Java for the backend and Java Servlet Pages (JSP) to develop dynamic web interfaces.

\section{b. PostgreSQL}

PostgreSQL is an open source Relational Database Management System (RDBMS) that uses Structured Query Language (SQL) for adding, retrieving, updating and deleting information stored in a database. It is used for accessing and processing data in a database. PostgreSQL was used because it is designed as a multitasking/multi-user database, which is one of the main requirements for a database to be used for implementing the proposed system.

\section{c. HTML.}

HTML simply refers to as Hypertext Markup Language. It was used for describing web pages.

\section{d. Bootstrap.}

Bootstrap is a technique of loading into a computer a few initial instructions that enable the introduction by the rest of the program from an input device. Bootstrap is the most popular HTML, CSS and JS framework for developing responsive, mobile fast projects on the web.

\section{System Testing and Validation}

At the end of the implementation phase, the system was tested to ensure it attains the stated objectives. We focused on the systematic discovery and debugging of defects. The following procedures were used to test the system:

i. Unit testing where each component of the system was independently tested.

ii. Integration testing where all system components were tested as a whole.

iii. And finally, user acceptance testing for the system to be tested by a small number of end-users of the system.

iv. Once these phases were completed, the system was ready for installation, migration, support and maintenance. 
Unit testing is a type of testing to check if the small piece of code is doing what it is supposed to do. For every component or module developed, we shall do unit testing to test for its functionality. The code must pass the test to be validated.

Integration testing is a type of testing to check if different pieces of the modules are working together.

\section{System Study, Analysis and Design}

This chapter defined the revisions carried out on the existing system at China-Uganda Friendship Hospital, Naguru, and requirements evaluated for the new system using procedure and data representation designs.

\section{System Study}

In order for the project team to understand and gain requirements of the new system, the current Antenatal Management Information system was studied. The system was studied by interaction with some of the personnel working in the hospital by asking them a series of informal questions to obtain knowledge and understanding of the entire records kept at the hospital facility and the activities carried out in general. The interview data was recorded and then transcribed to produce text that was analyzed using quantitative and qualitative methods of data analysis. Using the observation technique, we learnt about the sensitive issues that the participants in the existing system were unwilling to talk about. Furthermore, we acquired contextual information needed to frame the evaluation and make sense of the data collected using other techniques.

The data collected was analyzed using both structured and non-structured analysis approaches. Using the above techniques, we were able to understand the existing system and to gain the users opinions about the existing and the new system.

\section{Existing System}

China-Uganda Friendship Hospital, Naguru, at the moment uses a paper-based information management system to manage their records, create records, backup and generate reports. On arrival, each antenatal client is required to possess a 32-page exercise book in which their vitals are recorded, their biodata is captured and entered into the HMIS registry and then sent for triage. At triage, the client's vitals are captured and recorded in their exercise book. If it is their first visit, they are given an examination progress card and their obstetrics history is captured and filled in the card. After this, they are sent for examination by specialized personnel where their monthly visit progress is captured and recorded on the examination progress card. At the end of the month, the doctor in charge files a report on the number of clients that have been serviced all month long.

\section{DATA ANALYSIS RESULTS}

The techniques used for data collection were observation and interviews where we acquired meaningful insights from the dataset. After data collection, we analyzed the data, structuring the findings from the survey research in order to obtain accurate information about the existing and the new system. 


\section{Interview}

Interview technique was used to gain more information about the existing system being used for Antenatal Information Management at China-Uganda Friendship Hospital, Naguru, to achieve requirements for the new system. Major stakeholders were interviewed face to face from the records officer to senior clinical officer and to the head midwife. An interview guide was planned and used which involved a set of questions to which respondents gave answers based on their experience and personal understanding of the existing system. All the answers from the respondents were recorded and analyzed for further understanding of the existing system.

Below are the findings of the interview:

Table 1: Analysis of interviews

\begin{tabular}{|l|l|l|l|}
\hline Question & $\begin{array}{l}\text { Answer (1) Records } \\
\text { Officer }\end{array}$ & $\begin{array}{l}\text { Answer (2) Head } \\
\text { Midwife }\end{array}$ & Conclusion \\
\hline $\begin{array}{l}\text { Is it easy to keep } \\
\text { track of records using } \\
\text { the existing system? }\end{array}$ & $\begin{array}{l}\text { It requires more time } \\
\text { to go through files of } \\
\text { previously recorded } \\
\text { client visits. }\end{array}$ & $\begin{array}{l}\text { It is not easy, since } \\
\text { not all recorded } \\
\text { information is found } \\
\text { at the time of review } \\
\text { since clients leave } \\
\text { with their exercise } \\
\text { books containing } \\
\text { records. }\end{array}$ & $\begin{array}{l}\text { The existing system } \\
\text { is not capable of } \\
\text { tracking records } \\
\text { because all records } \\
\text { are kept in a file } \\
\text { system format, which } \\
\text { is tedious to those in } \\
\text { charge of maintaining } \\
\text { the record } \\
\text { consistency. }\end{array}$ \\
\hline $\begin{array}{l}\text { Is the process of } \\
\text { recording and } \\
\text { keeping antenatal } \\
\text { records reliable? } \\
\begin{array}{l}\text { Give reason for your } \\
\text { answer. }\end{array}\end{array}$ & $\begin{array}{l}\text { No, because clients } \\
\text { take the exercise } \\
\text { books containing } \\
\text { their records with } \\
\text { them and may lose } \\
\text { them before they } \\
\text { come for the next } \\
\text { visit. }\end{array}$ & $\begin{array}{l}\text { No, because clients } \\
\text { come in large } \\
\text { numbers compared to } \\
\text { the official stationery } \\
\text { supplied by the } \\
\text { Ministry of Health. } \\
\text { So, some clients data } \\
\text { are not entered into } \\
\text { the official } \\
\text { documentation, } \\
\text { making it hard to file } \\
\text { reports. }\end{array}$ & $\begin{array}{l}\text { The existing system } \\
\text { tiresome because all } \\
\text { client records are } \\
\text { recorded manually on } \\
\text { paper which is also } \\
\text { not adequate, making } \\
\text { it hard } \\
\text { to generate reports } \\
\text { for } \\
\text { the department. }\end{array}$ \\
\hline $\begin{array}{l}\text { Does it have an } \\
\text { impact on your work? } \\
\text { impow does it have an }\end{array}$ & $\begin{array}{l}\text { Yes, it impacts on the } \\
\text { especially on } \\
\text { generation of reports } \\
\text { concerning } \\
\text { department progress. }\end{array}$ & $\begin{array}{l}\text { Yre because there } \\
\text { delays with the } \\
\text { process of ordering } \\
\text { for supplies since the } \\
\text { entire management } \\
\text { system is } \\
\text { manual and all } \\
\text { records are on paper; } \\
\text { so, it delays in }\end{array}$ & $\begin{array}{l}\text { The system requires a } \\
\text { faster report } \\
\text { generation process } \\
\text { and real time } \\
\text { communication in } \\
\text { order to satisfy all } \\
\text { units in the } \\
\text { department. }\end{array}$ \\
\hline
\end{tabular}




\begin{tabular}{|l|l|l|l|}
\hline & & $\begin{array}{l}\text { helping to know } \\
\text { which unit in the } \\
\text { department requires } \\
\text { what supplies. }\end{array}$ & \\
\hline $\begin{array}{l}\text { What solution do can } \\
\text { yoummend? }\end{array}$ & $\begin{array}{l}\text { Need of a system that } \\
\text { auto generates } \\
\text { official forms, to } \\
\text { boost the } \\
\text { process of recording } \\
\text { client data and has } \\
\text { real-time } \\
\text { communication and } \\
\text { ensures security. }\end{array}$ & $\begin{array}{l}\text { Need of faster } \\
\text { report generating } \\
\text { system to enhance } \\
\text { and automate report } \\
\text { generation, and easy } \\
\text { monitoring on the } \\
\text { records and the } \\
\text { department } \\
\text { requirements. }\end{array}$ & $\begin{array}{l}\text { There is need for an } \\
\text { Information } \\
\text { Management System } \\
\text { for China-Uganda } \\
\text { Friendship Hospital, } \\
\text { Naguru. }\end{array}$ \\
\hline
\end{tabular}

\section{Strengths and Weaknesses of the Existing System}

The existing system, currently being the most used and dependable method across the country by most health facilities even though slightly computerized, has its strengths and weaknesses.

\section{a) Strength}

The strength of the existing system is as follows:

i. The existing system doesn't need computer knowledge or specialized professional personnel to maintain and work with the system.

ii. The current system doesn't need internet connection, daily fee of internet subscriptions with the internet service provider (ISP) or an area supporting internet service in order to manage antenatal records.

iii. The current system doesn't require purchase of hardware or subscriptions to software for system update or upgrades of the operating system in order to manage records.

\section{b) Weaknesses}

The weaknesses of the existing system are as follows:

i. Records kept in paper increase the chance of data loss due to bulk files requiring extra time to recover the records or to go through all the files and papers to find the needed information, hence slowing down decision making by the management.

ii. Less security of client records since they are kept using the file system which does not require authentication of user password to gain access to the client records which are confidential data, that is, only restricted to staff at the facility.

iii. Inconsistency in data entry, proneness to errors, and mistaking of information due to less certainty of the records gathered during daily activities. 
iv. Time consuming and costly to produce monthly reports since all records are kept in paper form stored in files, hence requiring one to type the record reports in the computer in order to print out reports which require extra money for the service.

v. Difficulty in making backups of records since all records are on paper and kept in files which would require extra space and effort to go through all paper records and rewrite them on other paper; this is costly and tiresome.

\section{System Analysis}

Based on the outcomes from the system study the users, functional and non-functional requirements of the Antenatal Information Management System were evaluated as follows:

\section{User Requirements}

From the system study, four users of the system were recognized. These are system administrator, records officer, senior clinical officer and head midwife. Their requirements in the system include the following:

a) System Administrator: The administrator is the person that manages the computer systems in the organization. His requirements in the system include

i. User registration (setup and maintain account)

ii. Maintain system

iii. Verify that peripherals are working properly

iv. Monitor system performance

v. Install software

vi. Create a backup and recovery policy

vii. Password and identity management.

b) Records Officer: The records officer is the person that is responsible for registration and queuing clients for service. His requirements in the system are as follows:

i. Able to account for daily clients count

ii. Able to register clients

iii. Able to queue clients for service

iv. Able to view serviced clients' statistics.

c) Senior Clinical Officer: The senior clinical officer is a person that is responsible for the triaging of the clients and capturing their vitals. His requirements are as follows:

i. Able to capture client vitals

ii. Able to triage clients 
iii. Able to refer patients for consultation and examination

iv. Able to view serviced clients' statistics.

d) Head Midwife: The head midwife is a person that is responsible for carrying out antenatal progress examination and prescription of the needed drugs as per trimester. The head midwife's requirements include

i. Able to do antenatal progress examination

ii. Able to prescribe drugs

iii. Able to view serviced clients' statistics.

\section{Functional Requirements}

The functional requirements are activities that the system must be able to perform. The system provides the following functionalities:
a. It should be able to store user details
b. It should be able to provide views for all stored details
c. It should be able to register clients' details
d. It should have a simple user interface
e. It should be able to generate and print reports.

\section{Nonfunctional Requirements}

Nonfunctional requirements are the constraints that should be enforced on the services provided by the existing system. The system was designed to meet the following nonfunctional requirements:

a. The system should verify or validate all user inputs and update accordingly

b. The system should be robust and able to run on most platforms with no errors

c. The system should be user friendly

d. The system should be complete, consistent and reliable to the user

e. The system must not allow unauthorized users to access stored data

f. The system should be able to produce expected results when supplied with right inputs.

\section{System Design}

The system was designed using process and data models. The design used to describe the system includes system architecture, level One DFD and database design. 


\section{Architectural Designs of the System}

The architectural design gives a high-level view of the new system with the main components of the system and services they provide, as well as how they communicate. The system is implemented using a three-tier architecture that encompasses user interface, process management and DBMS as illustrated below. This structure ensures that users' interaction with the system is independent of storage consideration.

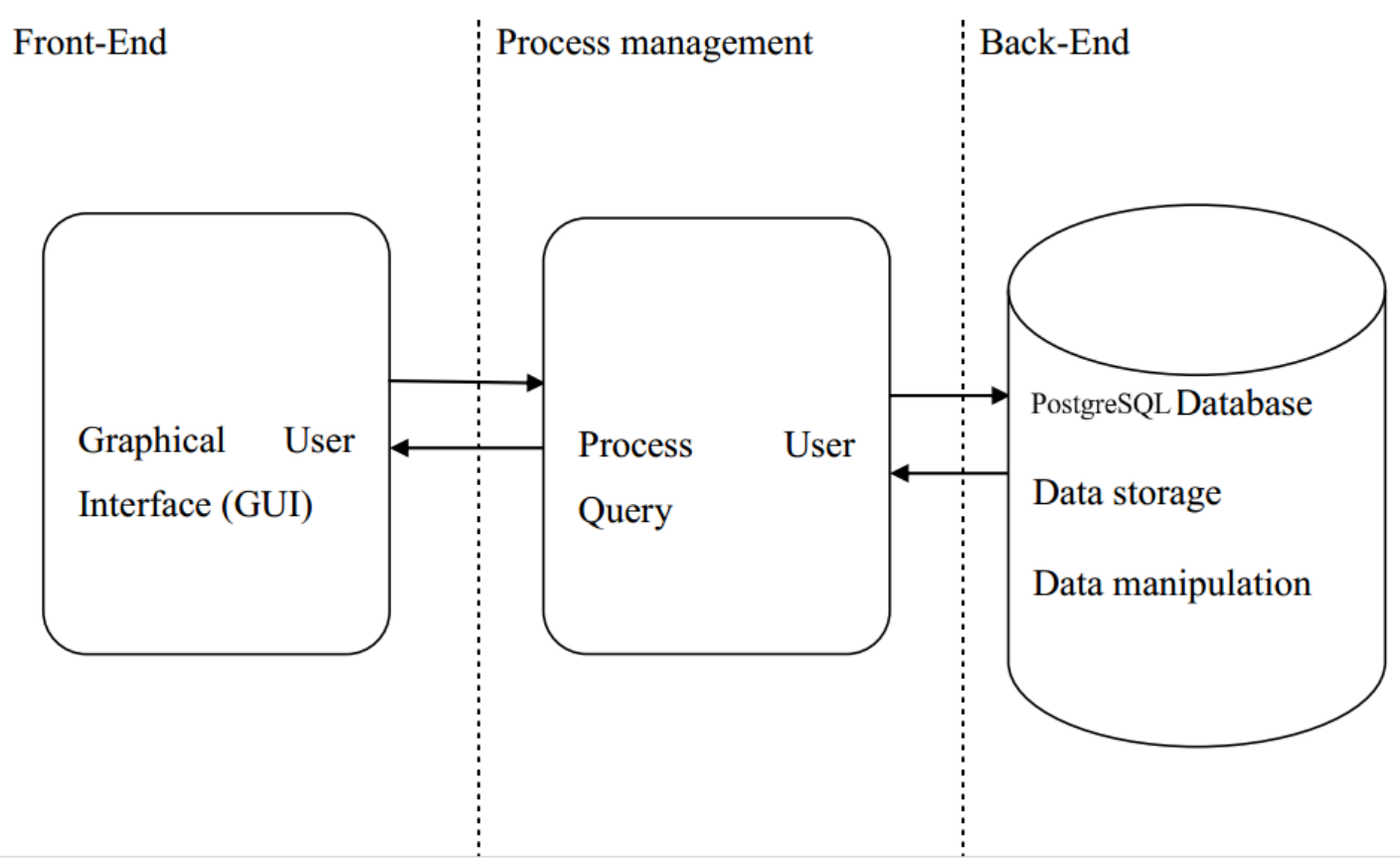

Figure 1: System architecture

\section{Process Modeling}

In process modeling, the sequence diagram was used to model the flow of logic within the proposed system in a visual manner. It shows the major sub-processes identified in the Antenatal Management Information System. Data obtained from the Data Flow Diagram (DFD) was collectively used to produce the Data Dictionary (DD) of the system. 
British Journal of Computer, Networking and Information Technology

ISSN: 2689-5315

Volume 5, Issue 1, 2022 (pp. 11-42)

a) Key symbols in process modeling
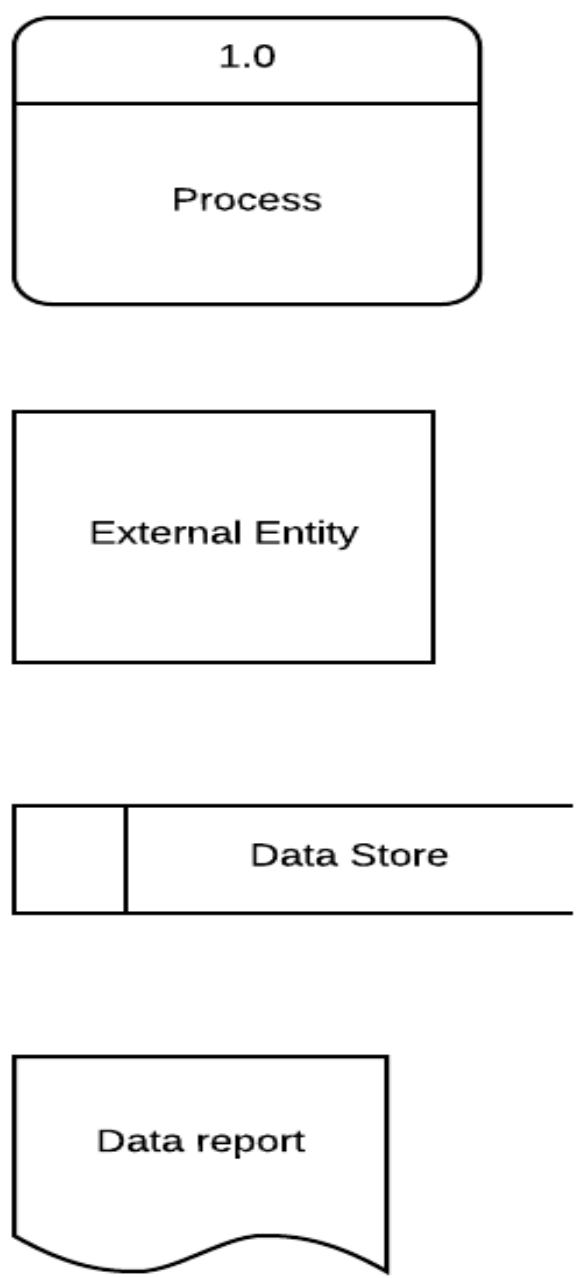

-Data flow

Figure 2: Symbols used in process modeling 
British Journal of Computer, Networking and Information Technology

ISSN: $2689-5315$

Volume 5, Issue 1, 2022 (pp. 11-42)

www.abjournals.org

b) Context diagram

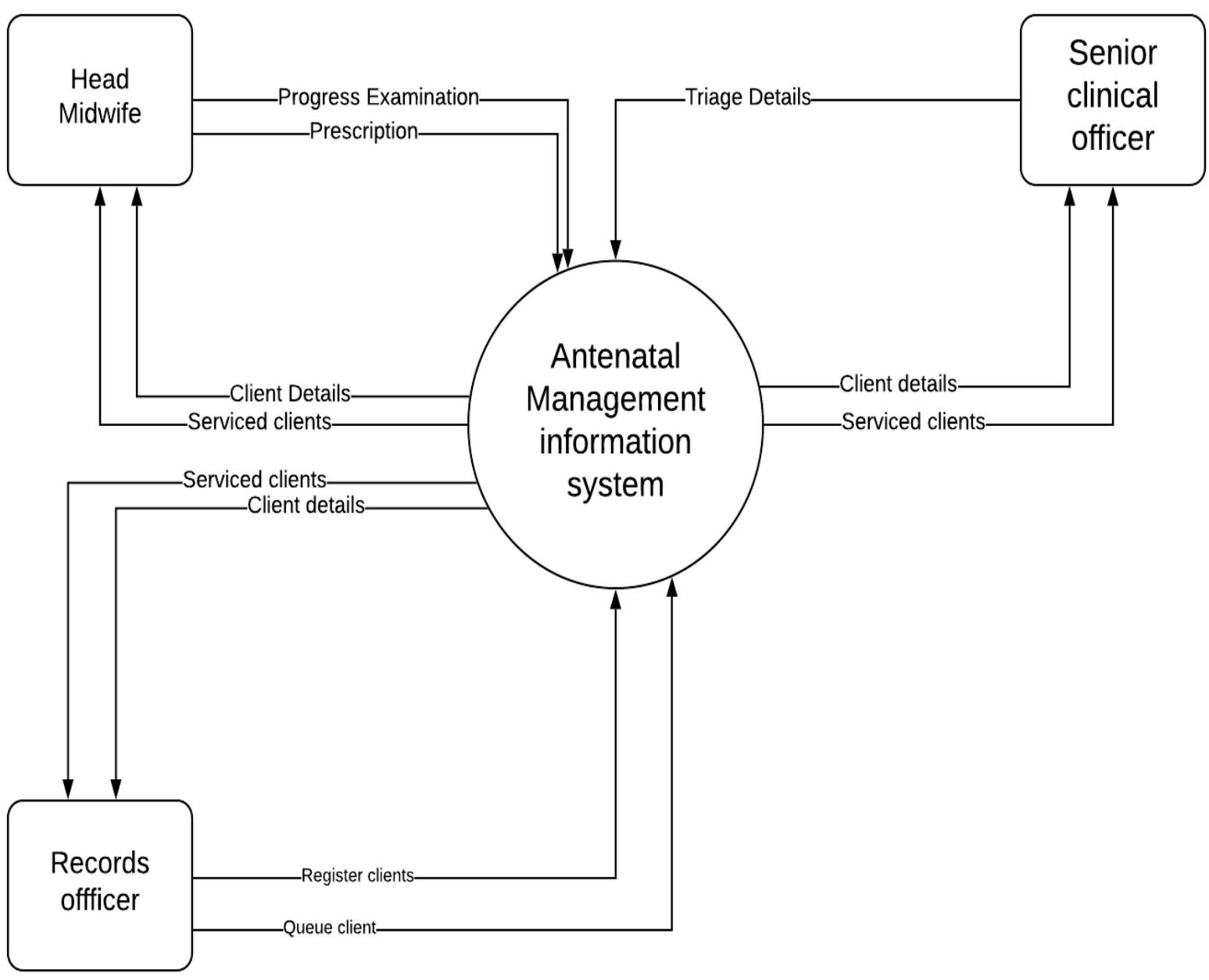

Figure 3: Context diagram for antenatal management information system 
British Journal of Computer, Networking and Information Technology

ISSN: $2689-5315$

Volume 5, Issue 1, 2022 (pp. 11-42)

www.abjournals.org

\section{c) Level 1 data flow diagram}

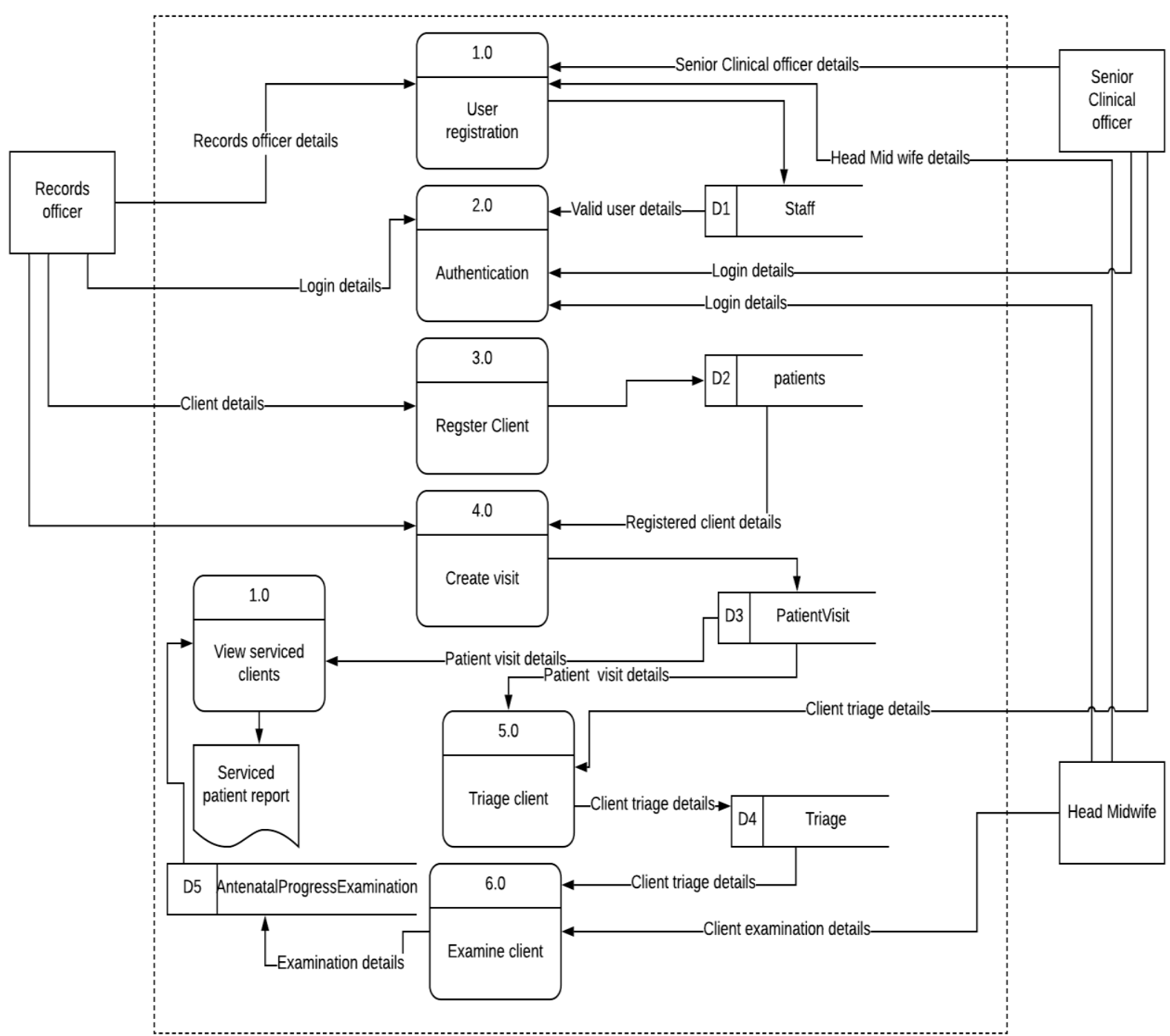

Figure 4: Level 1 data flow diagram for the antenatal management information system 


\section{d) Data dictionary of level 1 DFD of the antenatal management information system}

Below are the descriptions of all the design objects used in the system development of an Antenatal Management Information System. These objects include processes, data stores, and the external entities involved in the system.

\section{Table 2: Description of process}

\begin{tabular}{|l|l|}
\hline Process & Description \\
\hline User registration & $\begin{array}{l}\text { Allows the head midwife, records officer and } \\
\text { the Senior clinical officer to insert their } \\
\text { details into the system. }\end{array}$ \\
\hline Authentication & $\begin{array}{l}\text { Allows the system to authenticate registered } \\
\text { users and provide authentication responses. }\end{array}$ \\
\hline Register client & $\begin{array}{l}\text { Allows the records officer to register new } \\
\text { antenatal clients and view those already } \\
\text { existing respectively. }\end{array}$ \\
\hline Create visit & $\begin{array}{l}\text { Allows the records officer to create/instantiate } \\
\text { a unique visit for the client so as to service } \\
\text { them. }\end{array}$ \\
\hline Triage client & $\begin{array}{l}\text { Allows the clinical officer to capture patient } \\
\text { vitals and refer them for examination } \\
\text { respectively. }\end{array}$ \\
\hline Examine client & $\begin{array}{l}\text { Allows the head midwife to perform the } \\
\text { antenatal progress examination on the client } \\
\text { and prescribe drugs respectively. }\end{array}$ \\
\hline View serviced clients & \begin{tabular}{l} 
Generates serviced clients report. \\
\hline
\end{tabular}
\end{tabular}

Table 3: Description of data stores

\begin{tabular}{|l|l|}
\hline Data Stores & Description \\
\hline System user & Stores details of registered users in the system \\
\hline Patients & Stores client details \\
\hline Patient Visit & Stores client visit details \\
\hline Triage & Stores triage details \\
\hline Antenatal Progress Examination & Stores progress examination details \\
\hline
\end{tabular}


Table 4: Description of external entities

\begin{tabular}{|l|l|}
\hline External entity & Description \\
\hline Records officer & $\begin{array}{l}\text { Responsible for registering clients and } \\
\text { creating new client visits; views serviced } \\
\text { clients reports. }\end{array}$ \\
\hline Senior clinical officer & $\begin{array}{l}\text { Responsible for capturing client vitals and } \\
\text { referring them for examination; views } \\
\text { serviced clients report. }\end{array}$ \\
\hline Head midwife & $\begin{array}{l}\text { Responsible for performing the progress } \\
\text { examination, prescribing drugs; views } \\
\text { serviced clients report. }\end{array}$ \\
\hline
\end{tabular}

\section{Data Modeling}

The data modeling of the system was done by ascertaining the data requirements, entities and their related attributes that make up the system. Modeling of the relationships between the entities were designed with an enriched entity relationship diagram for the system.

\section{a) Data requirements}

i. Patient: This stores information about clients registered. The information stored includes the patient ID, first name, last name, middle name, current address, next of kin name, next of kin relationship, spoken languages, phone number, NIN, gender, and date of birth.

ii. Patient visit: This stores information about the client's specific visit. The information stored includes patient visit ID, patient ID, facility unit ID, unit service ID, and staff ID.

iii. Staff: This stores information about staff. The information stored includes first name, last name, middle name, role, address, email, username, password, and staff ID.

iv. Triage: This stores information about client vitals. The information stored includes patient visit ID, triage ID, temperature, height, muac, bp, para, abortions, gravida, weight, LNMP, edd, BMI, and staff ID.

v. Antenatal examination progress: This stores information about the client's progress. The information stored includes fundal height, week of_ammenorrhea, presentation, relation_to_brim, position, 1ie, return date, date, staff ID, and fetal heart. 
British Journal of Computer, Networking and Information Technology

ISSN: $2689-5315$

Volume 5, Issue 1, 2022 (pp. 11-42)

\section{b) Identification of entities and associated attributes}

Table 5: Entities and the associated attributes

\begin{tabular}{|c|c|}
\hline Entities & Attributes \\
\hline \multirow[t]{12}{*}{ Patient } & Patient ID \\
\hline & First name \\
\hline & Last name \\
\hline & Middle name \\
\hline & Current address \\
\hline & Next of kin name \\
\hline & Next of kin relationship \\
\hline & Spoken languages \\
\hline & Phone number \\
\hline & NIN \\
\hline & Gender \\
\hline & D.O.B. \\
\hline \multirow[t]{5}{*}{ Patient visit } & Patient visit ID \\
\hline & Patient ID \\
\hline & Facility unit ID \\
\hline & Unit service ID \\
\hline & Staff ID \\
\hline \multirow[t]{7}{*}{ Staff } & Staff ID \\
\hline & First name \\
\hline & Last name \\
\hline & Username \\
\hline & Password \\
\hline & Role \\
\hline & Email \\
\hline \multirow{14}{*}{ Triage } & Triage ID \\
\hline & Patient visit ID \\
\hline & Staff ID \\
\hline & LMP \\
\hline & $\mathrm{BP}$ \\
\hline & BMI \\
\hline & MUAC \\
\hline & Para \\
\hline & Abortions \\
\hline & Temperature \\
\hline & Height \\
\hline & Weight \\
\hline & Gravida \\
\hline & Edd \\
\hline
\end{tabular}


British Journal of Computer, Networking and Information Technology

ISSN: $2689-5315$

Volume 5, Issue 1, 2022 (pp. 11-42)

www.abjournals.org

\begin{tabular}{|l|l|}
\hline Antenatal Examination & Antenatal Examination ID \\
\cline { 2 - 2 } & Patient visit ID \\
\cline { 2 - 2 } & Fundal height \\
\cline { 2 - 2 } Weeks of amenorrhea \\
\cline { 2 - 2 } & Presentation \\
\hline & Lie \\
\cline { 2 - 2 } & Position \\
\cline { 2 - 2 } & Date \\
\hline & Return date \\
\hline & Staff ID \\
\hline & Fetal heart \\
\cline { 2 - 2 } & Relation to brim \\
\hline
\end{tabular}

\section{c) Modeling relationships between entities}

The relationships modeled depicted some possible associations between the entities identified. It also gives the corresponding multiplicities (participation and cardinality) among the entities of the system.

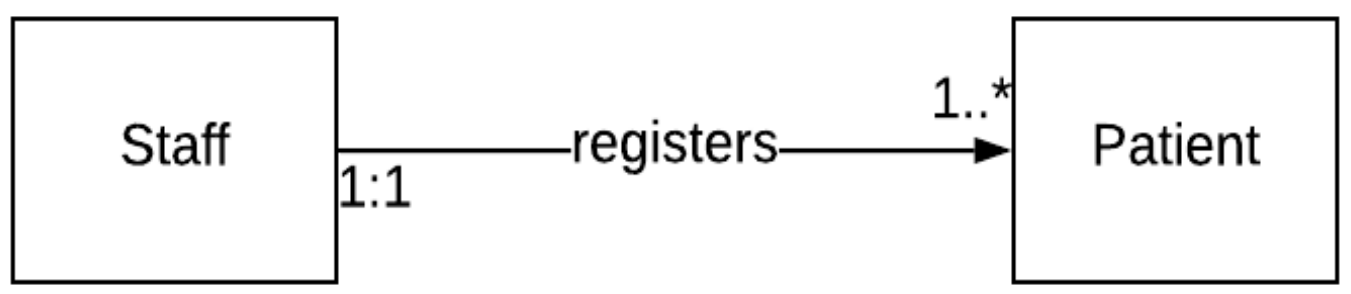

Figure 5: Relationship between staff and patient

The staff registers one or more patients and each patient is registered by a particular staff. Hence, the cardinality is $1: \mathrm{M}$.

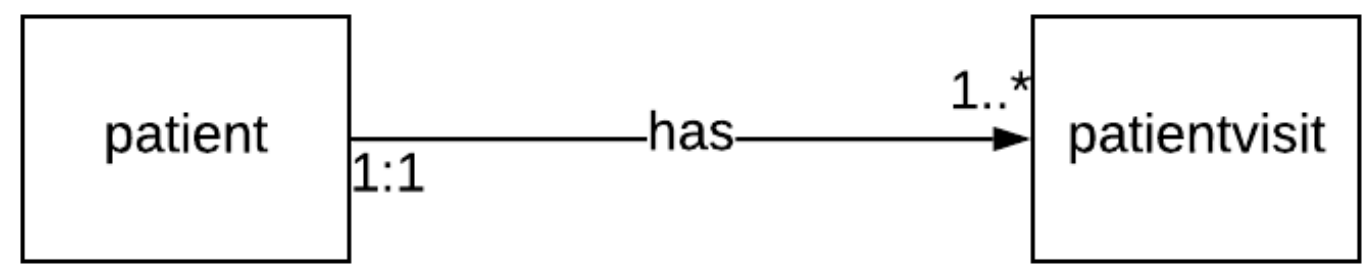

Figure 6: Relationship between patient and patient visit 
British Journal of Computer, Networking and Information Technology

ISSN: $2689-5315$

Volume 5, Issue 1, 2022 (pp. 11-42)

www.abjournals.org

A patient has one or more patient visits and each patient visit belongs to a particular patient. Hence, the cardinality is $1: \mathrm{M}$.

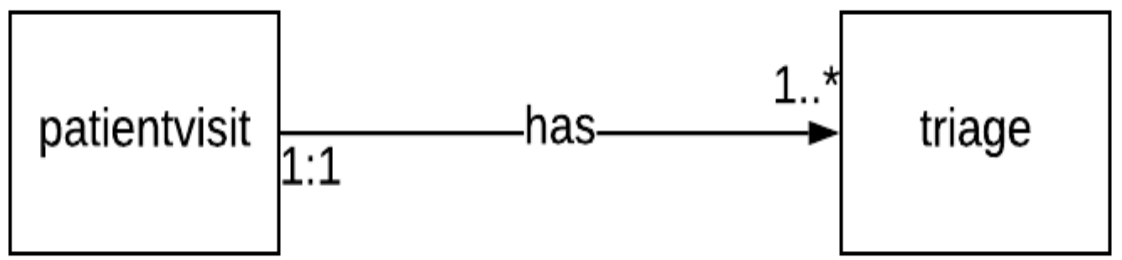

Figure 7: Relationship between the patient visit and triage

A patient visit has one or more triage records and each triage record belongs to a particular patient visit. Hence, the cardinality is 1:M.

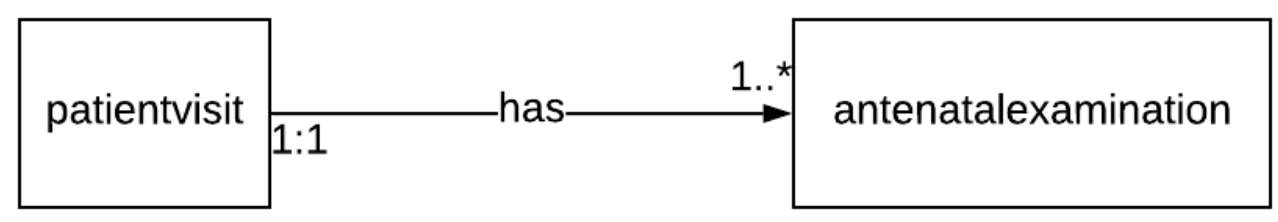

Figure 8: Relationship between a patient visit and antenatal examination

A patient visit has one or more antenatal examination records and each triage record belongs to a particular patient visit. Hence, the cardinality is $1: \mathrm{M}$.

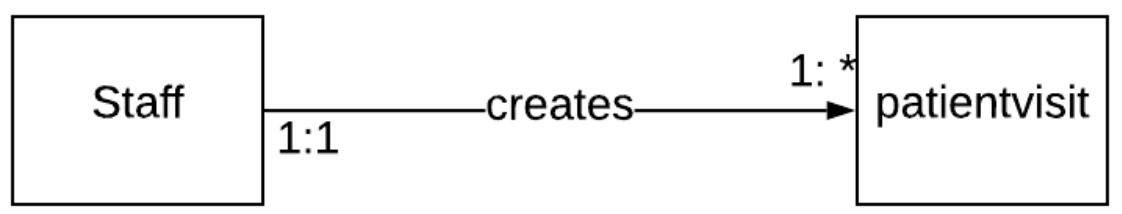

Figure 9: Relationship between staff and patient visit 
A patient visit has one or more antenatal examination records and each antenatal examination record belongs to a particular patient visit. Hence, the cardinality is 1: $\mathrm{M}$.

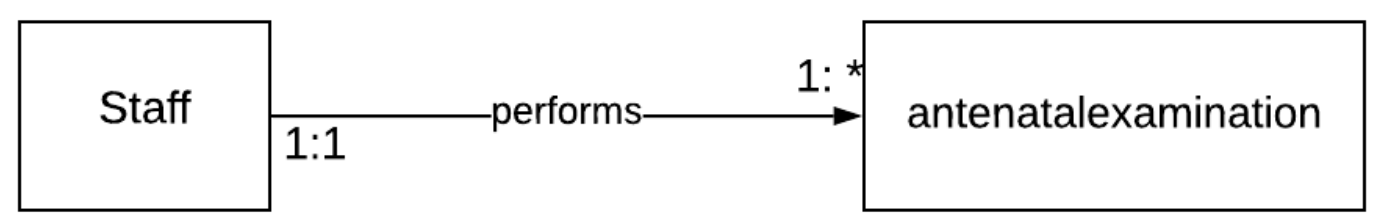

Figure 10: Relationship between staff and antenatal examination

A staff performs one or more antenatal examinations and each antenatal examination record belongs to a particular staff member. Hence, the cardinality is 1:M.

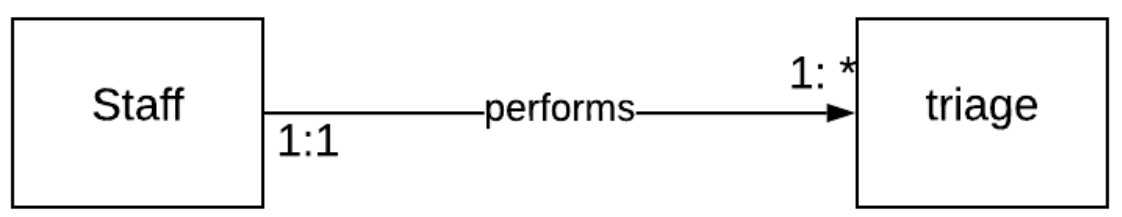

Figure 11: Relationship between staff and triage

A staff member performs one or more triage records and each triage record belongs to a particular patient visit. Hence, the cardinality is 1:M.

\section{d) The Entity Relationship Diagram (ERD)}

The ERD presented below depicted the entities, some of their attributes and the relationships between them as it was presented individually above. The diagram further indicates the multiplicities between these entities. Therefore, we decided to include the attributes in the ERD in order to avoid presenting an outrageous diagram. 
British Journal of Computer, Networking and Information Technology

ISSN: $2689-5315$

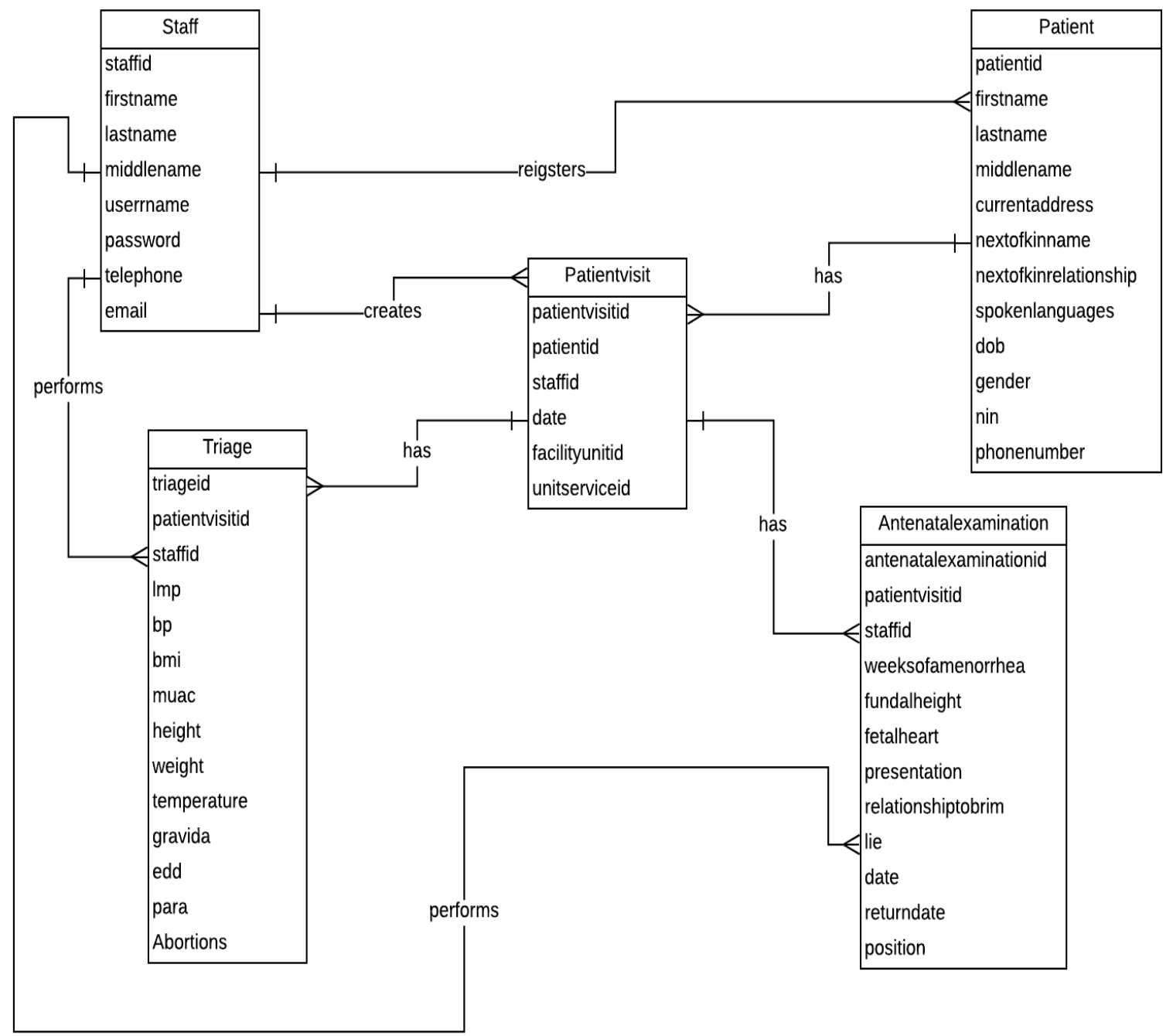

Figure 12: Entity relationship diagram of antenatal management information system

e) Structure of relationship of database

Table 6: Staff table structure

\begin{tabular}{|l|l|l|}
\hline Field name & Data type & Constraint \\
\hline Staff ID & Big Integer & $\begin{array}{l}\text { Primary key, auto increment, } \\
\text { not null }\end{array}$ \\
\hline First name & Text & Not null \\
\hline Last name & Text & Not null \\
\hline Other name & Text & \\
\hline Username & Varchar & Not null \\
\hline Password & Varchar & Not null \\
\hline Telephone & Varchar & Not null \\
\hline Email & Varchar & Not null \\
\hline
\end{tabular}


British Journal of Computer, Networking and Information Technology

ISSN: 2689-5315

Volume 5, Issue 1, 2022 (pp. 11-42)

www.abjournals.org

Table 7: Patient table structure

\begin{tabular}{|l|l|l|}
\hline Field name & Data type & Constraint \\
\hline Patient ID & Big Integer & $\begin{array}{l}\text { Primary key, auto increment, } \\
\text { not null }\end{array}$ \\
\hline First name & Text & Not null \\
\hline Last name & Text & Not null \\
\hline Middle name & Text & Not null \\
\hline Current address & Varchar & Not null \\
\hline Next of kin name & Text & Not null \\
\hline Spoken languages & Text & $\begin{array}{l}\text { Not null, foreign key } \\
\text { REFERENCES } \\
\text { Staff (staff ID) }\end{array}$ \\
\hline D.O.B. & Date & Not null \\
\hline Staff id & Big integer & Not null \\
\hline Phone number & & \\
\hline Gender & Varchar & \\
\hline Nin & Text & Varchar \\
\hline
\end{tabular}

Table 8: Patient visit table structure

\begin{tabular}{|l|l|l|}
\hline Field name & Data type & Constraint \\
\hline Patient visit ID & Big integer & $\begin{array}{l}\text { Primary key, not null, auto } \\
\text { increment }\end{array}$ \\
\hline Patient ID & Big integer & $\begin{array}{l}\text { Not null, Foreign key } \\
\text { REFERENCES } \\
\text { Patient (patient ID) }\end{array}$ \\
\hline Staff ID & Big integer & $\begin{array}{l}\text { Not null, Foreign key } \\
\text { REFERENCES } \\
\text { Staff (staff ID) }\end{array}$ \\
\hline Date & & Not null \\
\hline Facility unit ID & Date & Not null \\
\hline Unit service ID & Big integer & Not null \\
\hline & Big integer & \\
\hline
\end{tabular}

Table 9: Triage table structure

\begin{tabular}{|l|l|l|}
\hline Fields & Data type & Constraint \\
\hline Triage ID & Big Integer & $\begin{array}{l}\text { Primary key, not null, auto } \\
\text { increment }\end{array}$ \\
\hline Patient visit ID & Big Integer & $\begin{array}{l}\text { Not null, Foreign key } \\
\text { REFERENCES } \\
\text { Patient visit (patient visit ID) }\end{array}$ \\
& & $\begin{array}{l}\text { Not null, Foreign key } \\
\text { REFERENCES } \\
\text { Staff (staff ID) }\end{array}$ \\
\hline Staff ID & Big Integer & \\
\hline
\end{tabular}




\begin{tabular}{|l|l|l|}
\hline Lmp & Date & Not null \\
\hline Bp & Varchar & Not null \\
\hline Bmi & Integer & Not null \\
\hline Muac & Integer & Not null \\
\hline Height & Integer & Not null \\
\hline Weight & Integer & Not null \\
\hline Temperature & Varchar & Not null \\
\hline Gravida & Integer & Not null \\
\hline Edd & Date & Not null \\
\hline Para & Integer & Not null \\
\hline Abortions & Integer & Not null \\
\hline
\end{tabular}

Table 10: Antenatal examination table structure

\begin{tabular}{|l|l|l|}
\hline Fields & Data type & Constraint \\
\hline Antenatal examination ID & Big integer & $\begin{array}{l}\text { Primary key, not null, auto } \\
\text { increment }\end{array}$ \\
\hline Patient visit ID & Big integer & $\begin{array}{l}\text { Not null, Foreign key } \\
\text { REFERENCES } \\
\text { Patient visit (patient visit ID) }\end{array}$ \\
\hline Staff ID & Big integer & $\begin{array}{l}\text { Not null, Foreign key } \\
\text { REFERENCES } \\
\text { Staff (staff ID) }\end{array}$ \\
\hline Weeks of amenorrhea & Integer & Not null \\
\hline Fundal height & Integer & Not null \\
\hline Fetal heart & Integer & Not null \\
\hline Presentation & Text & Not null \\
\hline Relation to brim & Text & Not null \\
\hline Lie & Text & Not null \\
\hline Position & Text & Not null \\
\hline Date & Date & Not null \\
\hline Return date & Date & Not null \\
\hline & & \\
\hline
\end{tabular}

\section{System implementations, Testing and Validation}

\section{Functions Provided by the System}

The Antenatal Management Information System provides different functions to its users depending on their roles and access rights. The system prompts the users for their usernames and passwords - the users provide them then the system verifies the user. The user is then able to use the system for various tasks depending on his or her roles.

\section{Function Provided to Records Officer}

The system enables the records officer to register new patients and create new visits for them. He also views patient statistics and prints reports. 


\section{Functions Provided to Senior Clinical Officer}

The system allows the senior clinical officer to enter triage details of a patient and thereafter refer them for examination. He also views patient statistics and prints reports.

\section{Functions Provided to the Head Midwife.}

The system allows the head midwife to examine a patient and prescribe drugs. She can also view patient statistics and print reports.

\section{Sample Screen Shots Capture}

\section{System Login Page}

This shows the first page of the system. All the users have access to the system through this page. The users of the system have to be authenticated first by entering their required usernames and passwords before they can be able to access the system.

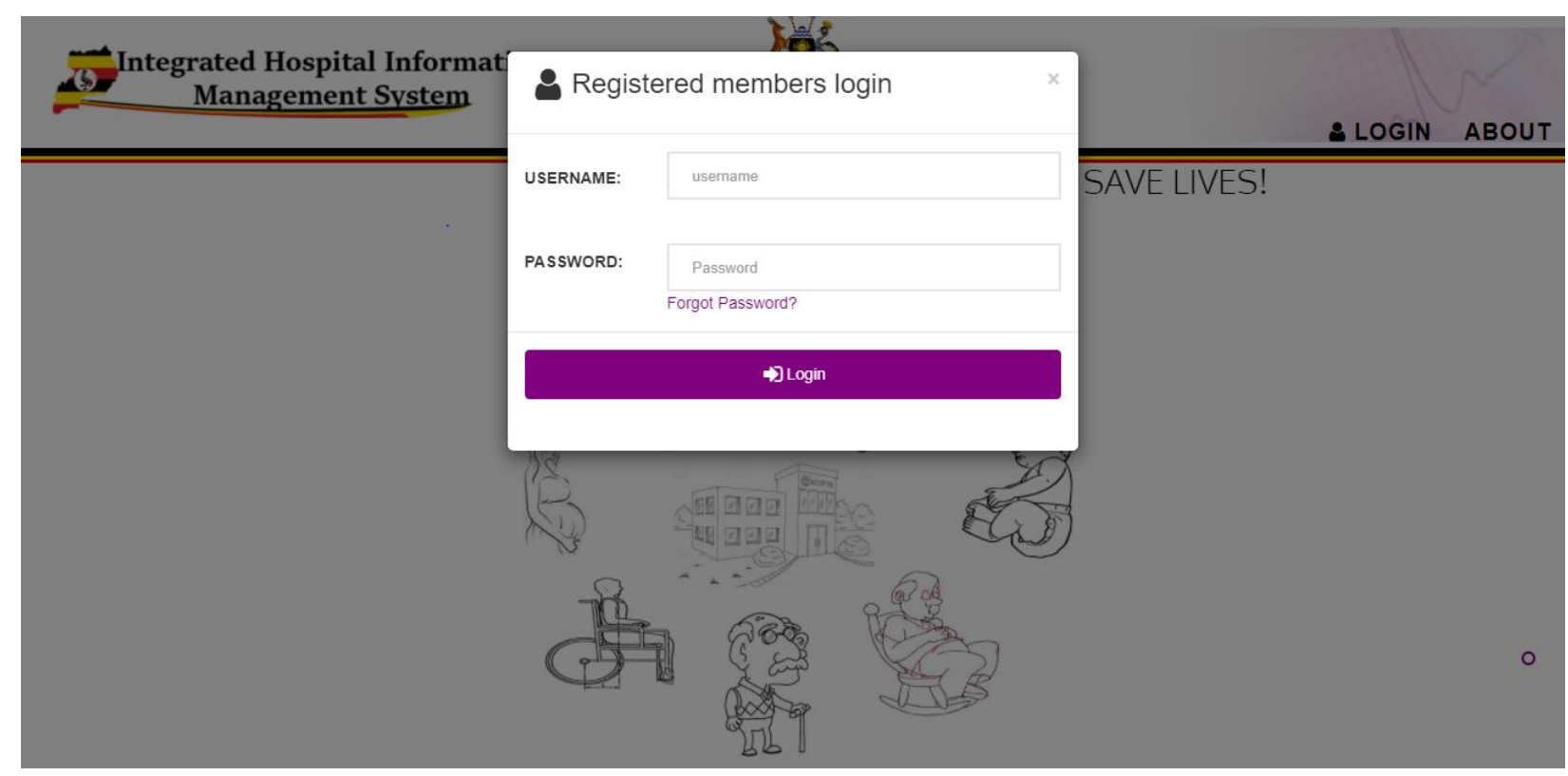

Figure 13: System login

\section{Authentication}

Authentication allows the system to authenticate registered users and provide authentication responses when wrong login details are used to have access to the system. 
British Journal of Computer, Networking and Information Technology

ISSN: $2689-5315$

Volume 5, Issue 1, 2022 (pp. 11-42)

www.abjournals.org

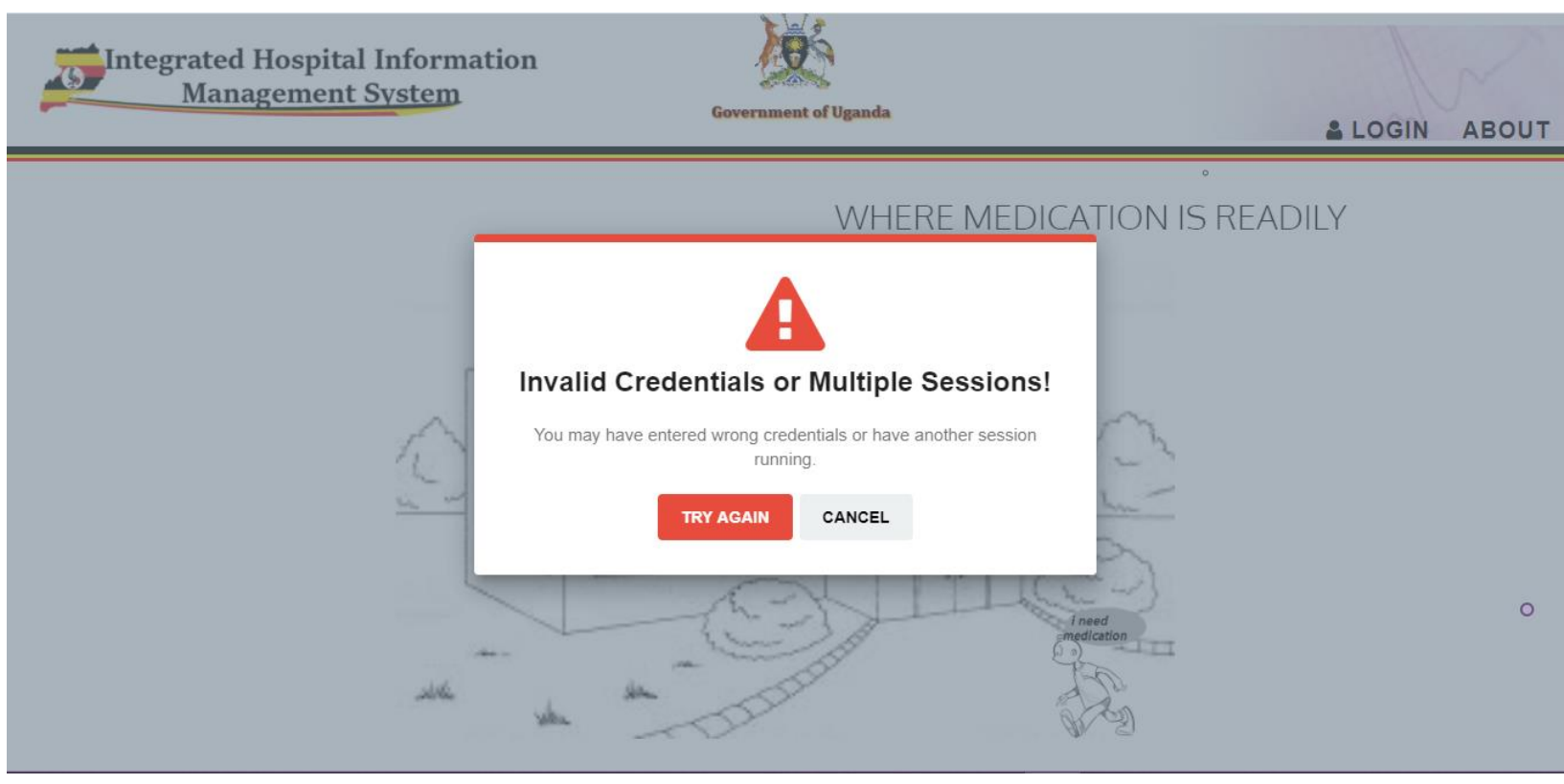

Figure 14: System authentication response

\section{Search Patient}

Search patient allows users to search for a patient and if they do not exist, prompts the user to register them as a new patient in the system.

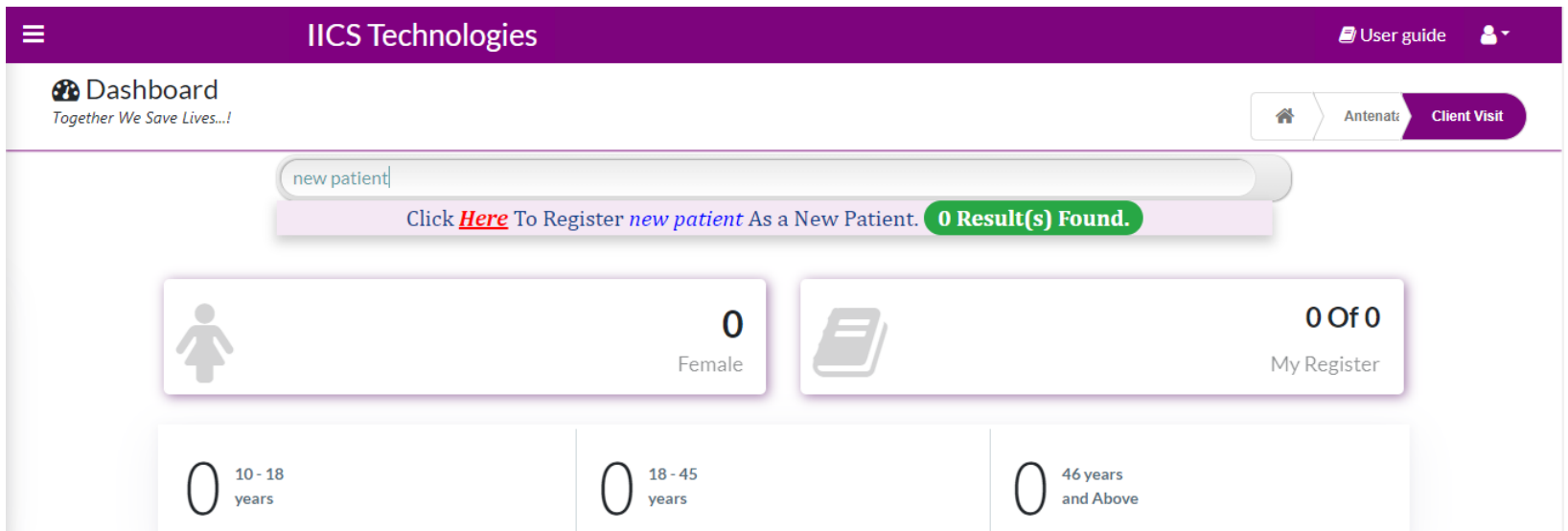

Figure 15: Search patient 
British Journal of Computer, Networking and Information Technology

ISSN: $2689-5315$

Volume 5, Issue 1, 2022 (pp. 11-42)

\section{Register Patient Form}

The registration form allows the user to register a new patient into the system.

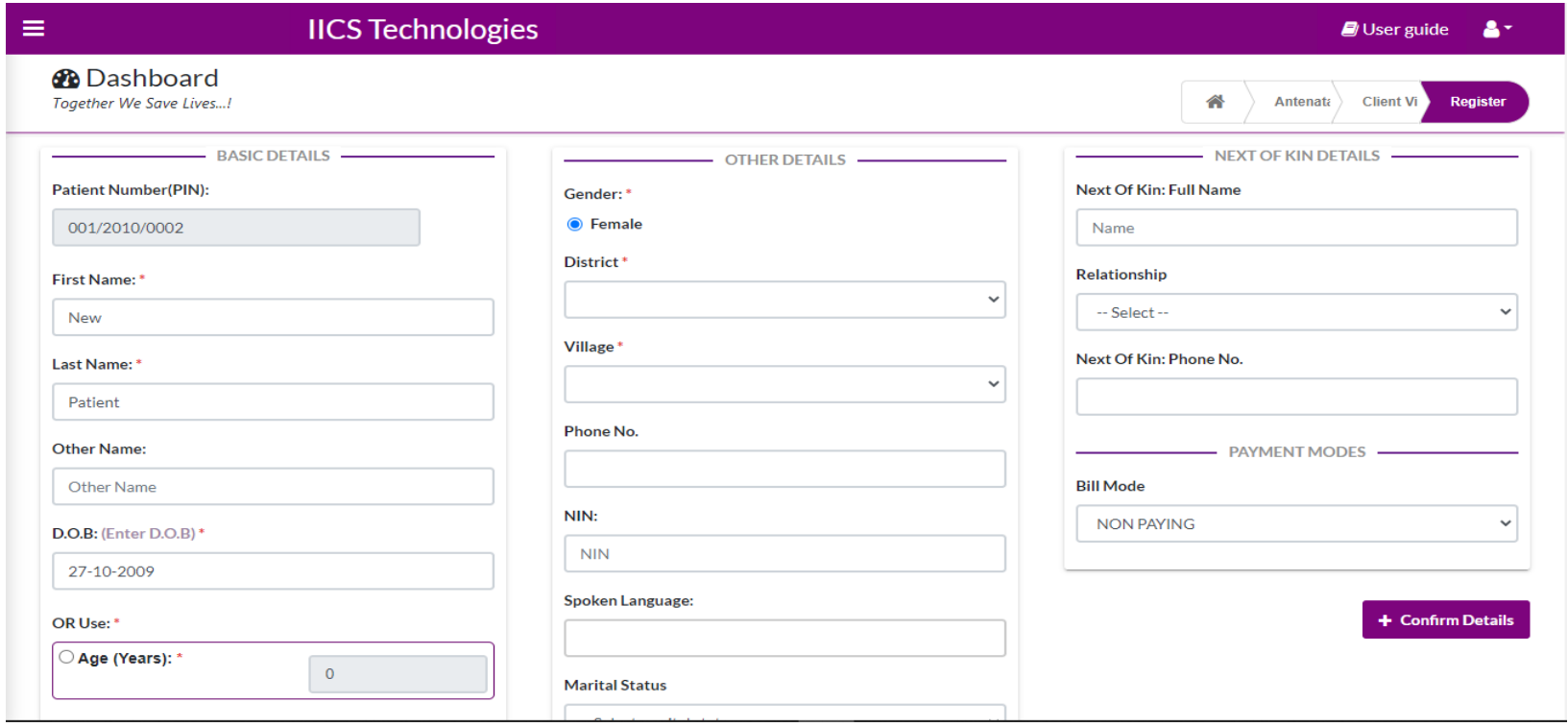

Figure 16: Patient registration form

\section{Patient Visit Form}

Patient visit form allows the user to create a new patient visit and queue the patient for the desired service.

\section{New Patient}

Patient Identification $\mathrm{No}$

001/2010/0002

Visit Number:

000110200131

Unit

No Record Found on This Patients' Social History, Allergies or Self-Medication!

Software Developers

Service

Antenatal Triage

Visit Type

New Visit

Visit Priority

Normal 
British Journal of Computer, Networking and Information Technology

ISSN: $2689-5315$

Volume 5, Issue 1, 2022 (pp. 11-42)

www.abjournals.org

\section{Triage Home}

The triage home page allows users to view how many patients are queued up for service and also allows them to pop the first patient in the queue.

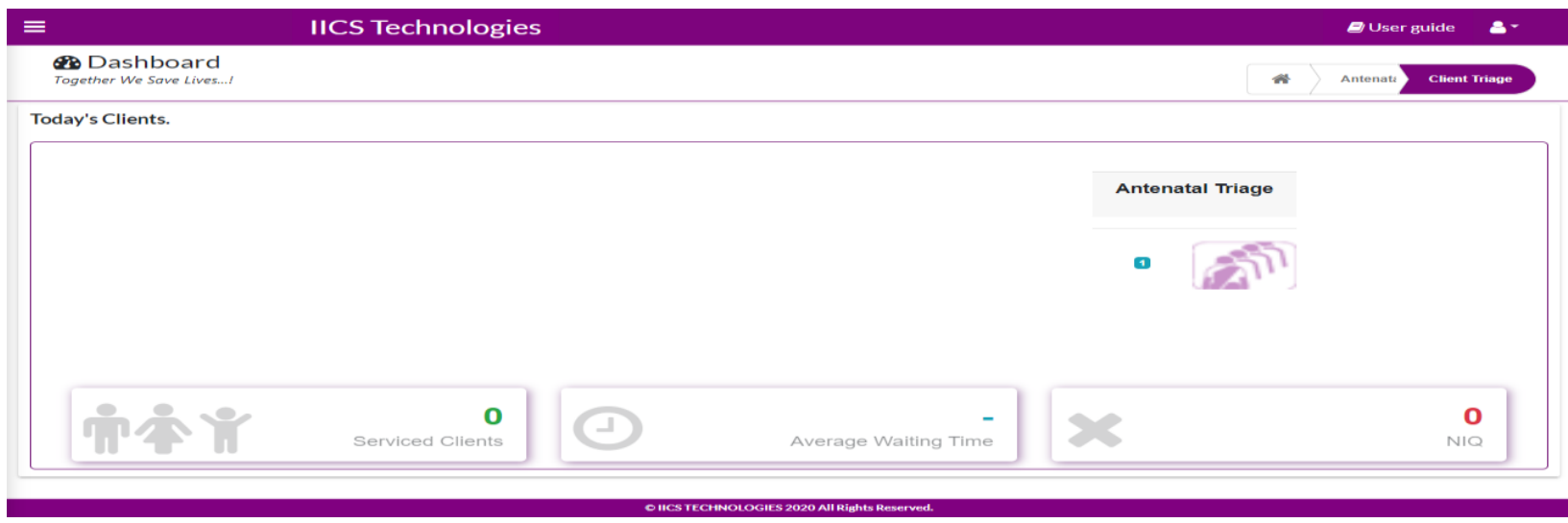

Figure 18: Triage home page

\section{Triage Form}

The triage form allows the user to capture patient vitals of the popped patient and thereafter forward them for clinical consultation.

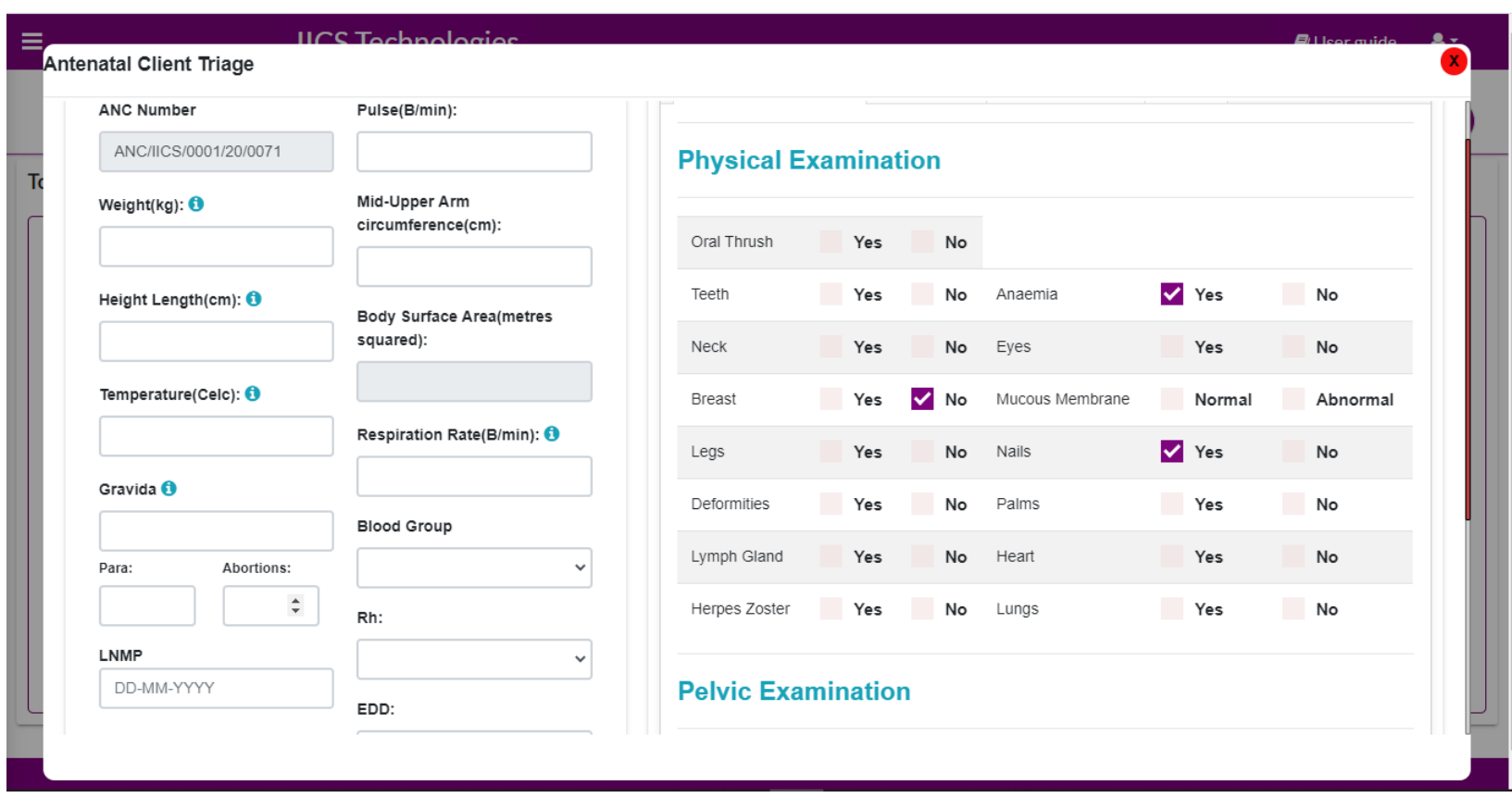

Figure 19: Triage form 
British Journal of Computer, Networking and Information Technology

ISSN: $2689-5315$

Volume 5, Issue 1, 2022 (pp. 11-42)

www.abjournals.org

\section{Clinical Consultation Home}

The Clinical consultation home page allows users to view how many patients are queued up for service and also allows them to pop the first patient in the queue.

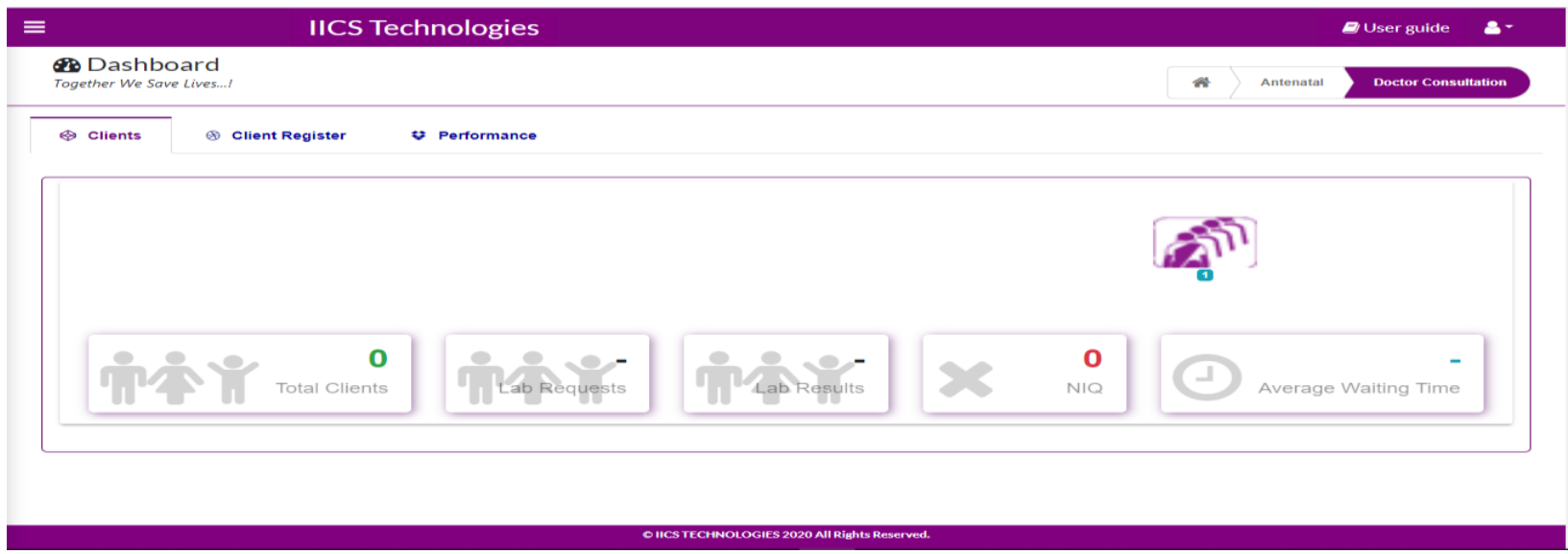

Figure 20: Clinical consultation home

\section{Antenatal Progress Examination Form}

The Antenatal Progress Examination form allows the system user to perform progress examinations and also view the patient's previous progress details.

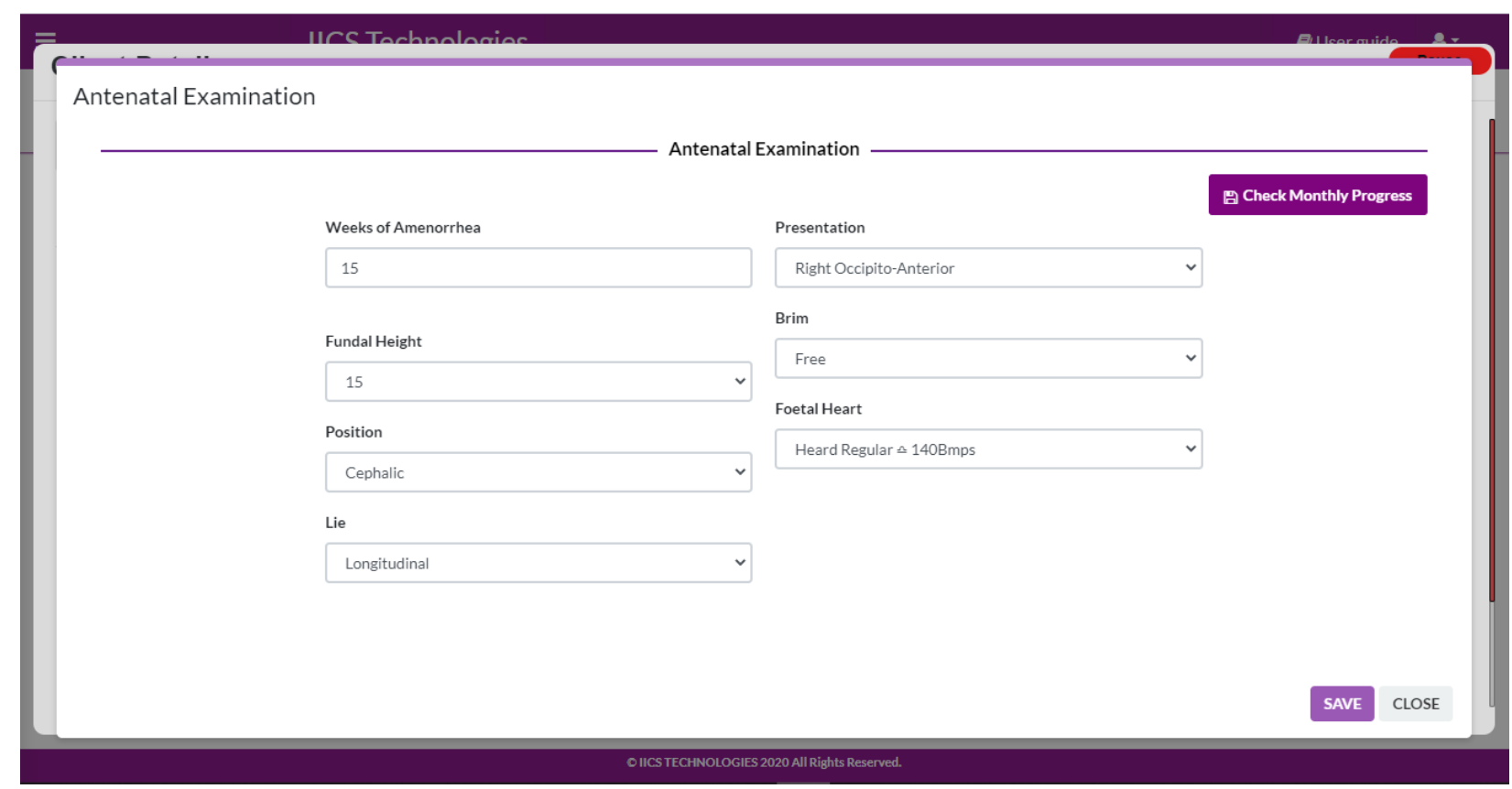

Figure 21: Antenatal progress examination 


\section{Patient Statistics}

The patient statistics view allows users to view patient statistics and also print out the required reports.

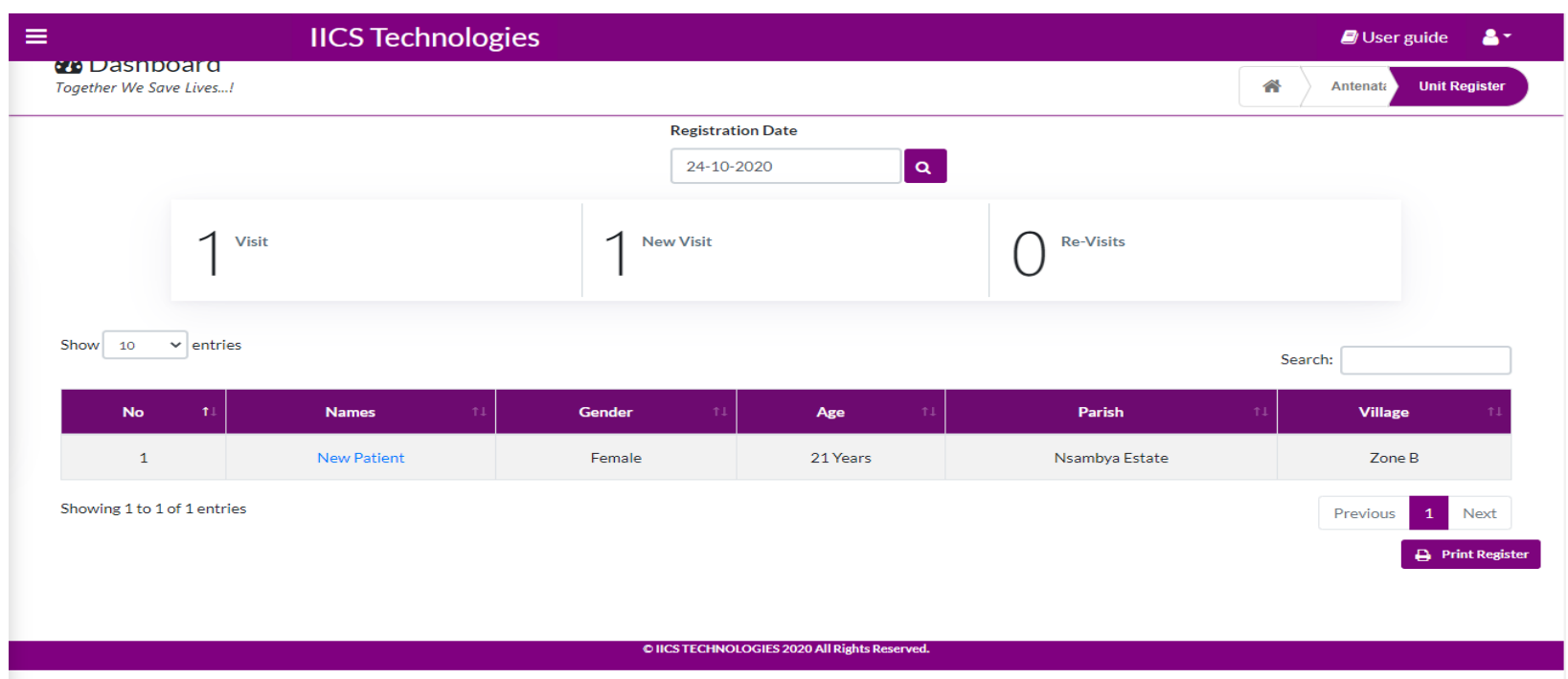

Figure 22: Patient statistics

\section{System Testing and Validation Results}

The Antenatal Management Information System was tested using unit, integration and system testing techniques. After every part of the system was implemented, it was tested using input to guarantee that each unit responded as expected. After individual units were tested as they were being developed, those whose functionality was associated with others were integrated and also tested using integrated testing. With this, interaction between these units was verified and defects also corrected. System testing was performed on the complete integrated system to check whether all the specified requirements were met. These three types of testing were done by the project team developers. User acceptance system was done by the users of the system. A sample of six users of the system each was used to test the system functionality.

In general, the users stated that the system had a clean layout, was simple and easy to learn. In other words, it was user friendly. They also commented that it will ease information management within the antenatal department. Below are some of the tested cases that were used to test the system: 
British Journal of Computer, Networking and Information Technology

ISSN: 2689-5315

Volume 5, Issue 1, 2022 (pp. 11-42)

www.abjournals.org

Table 11: Login test case

\begin{tabular}{|l|l|l|l|}
\hline Description & User's action & $\begin{array}{l}\text { Expected system } \\
\text { response }\end{array}$ & $\begin{array}{l}\text { Observed system } \\
\text { response }\end{array}$ \\
\hline $\begin{array}{l}\text { Login with right } \\
\text { password }\end{array}$ & Input right credentials & $\begin{array}{l}\text { Redirect user to } \\
\text { appropriate page }\end{array}$ & $\begin{array}{l}\text { System responded as } \\
\text { expected }\end{array}$ \\
\hline $\begin{array}{l}\text { Login with wrong } \\
\text { password }\end{array}$ & $\begin{array}{l}\text { Input wrong } \\
\text { credentials }\end{array}$ & $\begin{array}{l}\text { Prompt user to try } \\
\text { again with correct } \\
\text { credentials }\end{array}$ & $\begin{array}{l}\text { System responded as } \\
\text { expected }\end{array}$ \\
\hline
\end{tabular}

Table 12: Patient registration test case

\begin{tabular}{|l|l|l|l|}
\hline Description & User's action & $\begin{array}{l}\text { Expected system } \\
\text { response }\end{array}$ & $\begin{array}{l}\text { Observed system } \\
\text { response }\end{array}$ \\
\hline $\begin{array}{l}\text { User registers patient } \\
\text { into the system }\end{array}$ & $\begin{array}{l}\text { User enters patient } \\
\text { details in correct } \\
\text { format }\end{array}$ & $\begin{array}{l}\text { System creates new } \\
\text { patient }\end{array}$ & $\begin{array}{l}\text { System responded as } \\
\text { expected }\end{array}$ \\
\hline $\begin{array}{l}\text { User registers patient } \\
\text { with wrong format }\end{array}$ & $\begin{array}{l}\text { User enters patient } \\
\text { details with wrong } \\
\text { format }\end{array}$ & $\begin{array}{l}\text { Prompt user to enter } \\
\text { details in correct } \\
\text { format }\end{array}$ & $\begin{array}{l}\text { System responded as } \\
\text { expected }\end{array}$ \\
\hline
\end{tabular}

Table 13: Patient visit test case

\begin{tabular}{|l|l|l|l|}
\hline Description & User's action & $\begin{array}{l}\text { Expected system } \\
\text { response }\end{array}$ & $\begin{array}{l}\text { Observed system } \\
\text { response }\end{array}$ \\
\hline $\begin{array}{l}\text { User creates visit for } \\
\text { patient }\end{array}$ & $\begin{array}{l}\text { User creates new visit } \\
\text { for patient }\end{array}$ & $\begin{array}{l}\text { System queues } \\
\text { patient for service }\end{array}$ & $\begin{array}{l}\text { System responded as } \\
\text { expected }\end{array}$ \\
\hline $\begin{array}{l}\text { User creates visit for } \\
\text { patient already } \\
\text { queued }\end{array}$ & $\begin{array}{l}\text { User creates visit for } \\
\text { patient already } \\
\text { queued }\end{array}$ & $\begin{array}{l}\text { System responds } \\
\text { "Patient already } \\
\text { queued" }\end{array}$ & $\begin{array}{l}\text { System responded as } \\
\text { expected }\end{array}$ \\
\hline
\end{tabular}

Table 14: Triage test case

\begin{tabular}{|l|l|l|l|}
\hline Description & User's action & $\begin{array}{l}\text { Expected system } \\
\text { response }\end{array}$ & $\begin{array}{l}\text { Observed system } \\
\text { response }\end{array}$ \\
\hline $\begin{array}{l}\text { User captures patient } \\
\text { vitals into the system }\end{array}$ & $\begin{array}{l}\text { User enters patient } \\
\text { vitals in correct } \\
\text { format }\end{array}$ & $\begin{array}{l}\text { System creates new } \\
\text { triage record and } \\
\text { queues patient for } \\
\text { consultation }\end{array}$ & $\begin{array}{l}\text { System responded as } \\
\text { expected }\end{array}$ \\
\hline $\begin{array}{l}\text { User captures patient } \\
\text { vitals with wrong } \\
\text { format }\end{array}$ & $\begin{array}{l}\text { User enters patient } \\
\text { vitals with wrong } \\
\text { format }\end{array}$ & $\begin{array}{l}\text { Prompt user to enter } \\
\text { details in correct } \\
\text { format }\end{array}$ & $\begin{array}{l}\text { System responded as } \\
\text { expected }\end{array}$ \\
\hline
\end{tabular}


Table 15: Examination test case

\begin{tabular}{|l|l|l|l|}
\hline Description & User's action & $\begin{array}{l}\text { Expected system } \\
\text { response }\end{array}$ & $\begin{array}{l}\text { Observed system } \\
\text { response }\end{array}$ \\
\hline $\begin{array}{l}\text { User input patient } \\
\text { examination details } \\
\text { into the system }\end{array}$ & $\begin{array}{l}\text { User enters patient } \\
\text { examination details in } \\
\text { correct format }\end{array}$ & $\begin{array}{l}\text { System creates new } \\
\text { patient examination } \\
\text { record }\end{array}$ & $\begin{array}{l}\text { System responded as } \\
\text { expected }\end{array}$ \\
\hline $\begin{array}{l}\text { User inputs patient } \\
\text { examination with } \\
\text { wrong format }\end{array}$ & $\begin{array}{l}\text { User enters patient } \\
\text { examination details } \\
\text { with wrong format }\end{array}$ & $\begin{array}{l}\text { Prompt user to enter } \\
\text { details in correct } \\
\text { format }\end{array}$ & $\begin{array}{l}\text { System responded as } \\
\text { expected }\end{array}$ \\
\hline
\end{tabular}

Table 16: View patient statistics

\begin{tabular}{|l|l|l|l|}
\hline Description & User's action & $\begin{array}{l}\text { Expected system } \\
\text { response }\end{array}$ & $\begin{array}{l}\text { Observed system } \\
\text { response }\end{array}$ \\
\hline $\begin{array}{l}\text { User views serviced } \\
\text { patients in the system }\end{array}$ & $\begin{array}{l}\text { User tries to view } \\
\text { serviced patients } \\
\text { report }\end{array}$ & $\begin{array}{l}\text { System displays } \\
\text { report successfully }\end{array}$ & $\begin{array}{l}\text { System responded as } \\
\text { expected }\end{array}$ \\
\hline $\begin{array}{l}\text { No serviced patients } \\
\text { in the system }\end{array}$ & $\begin{array}{l}\text { User tries to view } \\
\text { services patients } \\
\text { report }\end{array}$ & $\begin{array}{l}\text { System to respond } \\
\text { "No patients found" }\end{array}$ & $\begin{array}{l}\text { System responded as } \\
\text { expected }\end{array}$ \\
\hline
\end{tabular}

\section{System Requirements}

In order for the system to perform as expected, the following system specification for hardware and software are essential:

\section{i. Hardware Requirements}

Table 17: Hardware requirements

\begin{tabular}{|l|l|}
\hline Hardware & System requirement(Minimum) \\
\hline Processor & Intel Pentium III \\
\hline Memory & 1024 RAM (2048 MB recommended) \\
\hline Disk space & $20 \mathrm{~GB}$ \\
\hline
\end{tabular}

\section{ii. Software Requirements}

Table 18: Software requirements

\begin{tabular}{|l|l|}
\hline Software & System requirement \\
\hline Operating system & $\begin{array}{l}\text { Microsoft Windows XP or higher, Linux Kali } \\
\text { or Higher, Mac OS }\end{array}$ \\
\hline Web browser & Google Chrome, Edge, Mozilla, Opera, etc. \\
\hline
\end{tabular}




\section{CONCLUSION}

The stated objectives of the Antenatal Management Information System were attained. The current system was studied, processed and data modeled for a new system. These were then designed and implemented, tested and validated as discussed in chapter five. In addition, all the requirements specified in the system analysis section were provided by the system. The system enables the records officer to register and view patients. The system enables the senior clinical officer to triage, capture patient vitals view, and print patient reports. The system enables the head midwife to examine the patients' monthly progress, view and print patient reports.

All in all, the Antenatal Management Information System addressed the hard-pressing challenges presented by the current system as it automated the whole patient flow in the hospital.

\section{Future Work}

Due to the inadequate time, some functionalities were not included in the system. The following enrichment could be made to the system:

i. Optimization on patient search: Fasten the patient's search based on a new search vector.

\section{REFERENCES}

Alkema, L. C. (2016). Global, regional, and national levels and trends in maternal mortality between 1990 and 2015, with scenario-based projections to 2030: a systematic analysis by the UN Maternal Mortality Estimation Inter-Agency Group. The Lancet, 387(10017), 462-474.

Anastasi, E. B. (2015). Losing women along the path to safe motherhood: why is there such a gap between women's use of antenatal care and skilled birth attendance? A mixed methods study in northern Uganda. BMC pregnancy and childbirth, 15(1), 287.

Conrad, P. D. (2012). Antenatal care services in rural Uganda: missed opportunities for goodquality care. Qualitative health research, 22(5), 619-629.

Daar, A. S. (2002). Top ten biotechnologies for improving health in developing countries. Nature genetics, 32(2), , 229-232.

Danlami, Y. A. (2018). Integrating Antenatal and Postnatal Pregnancy Services to Hospital Management System. Path of Science, 4, 1009-1015.

Endriyas, M. A. (2019). Understanding performance data: health management information system data accuracy in Southern Nations Nationalities and People's Region, Ethiopia. BMC health services research, 19(1), 175.

Essays, U. (November 2018). Web Based Information Systems. Retrieved May 2, 2020, from https://www.ukessays.com/essays/information-systems/web-based-informationsystems.php?vref $=1$

Jitta J, A.-W. J. (2008). Study of client satisfaction with health services in Uganda. Final report submitted to the Ministry of Health,. Retrieved from http://chdc.mak.ac.ug/publications/CHDC\%202008\%20Client\%20Satisfaction\%20with $\% 20$ Health\%20Services\%20in-Renamed.pdf 
Lincetto, O. M.-A. (n.d.). Antenatal care. Opportunities for Africa's newborns: Practical data, policy and programmatic support for newborn care in Africa, , 56-62.

Ministry of Health, R. o. (2015). docs. Retrieved from Ministry of Health, Republic of Uganda: http://www.health.go.ug/docs/HSSP_III_2010.pdf

Mpembeni, R. N. (2007). Use pattern of maternal health services and determinants of skilled care during delivery in Southern Tanzania: implications for achievement of MDG-5 targets. . BMC pregnancy and childbirth, 7(1), 29.

Namakula, S. \&. (2014). Examining health information systems success factors in Uganda's healthcare system.

Ngxongo, T. S. (2018). Basic Antenatal Care Approach to Antenatal Care Service Provision.

Organization, W. H. (2016). WHO recommendations on antenatal care for a positive pregnancy experience. WHO recommendations on antenatal care for a positive pregnancy experience., World Health Organization.

Organization., W. H. (2016). WHO recommendations on antenatal care for a positive pregnancy experience. World Health Organization.

Point, T. (2016). MVC Framework Introduction. . Retrieved April 25, 2020, from http://www. tutorialspoint. com/mvc_framework/mvc_framework_introductio n. htm.

Point, T. (2016). SDLC Waterfall Model. Retrieved April 25, 2020, from https://www. tutorailspoint. com/sdlc/sdlc_waterfall_model. htm

Ross, A. B. (2013). A low-cost ultrasound program leads to increased antenatal clinic visits and attended deliveries at a health care clinic in rural Uganda. PloS one, 8(10).

Umezuruike, C. N. (2017). Implementation Challenges Of Health Management Information Systems In Uganda: A Review. development 4(7).

UNICEF., \& United Nations Children's Fund (UNICEF). (2008). The state of the world's children 2009: maternal and newborn health (Vol. 9), Unicef.

Wikipedia. (2020). Management system. Retrieved from https://en.wikipedia.org/wiki/Management_system 